\title{
Oriental theileriosis in dairy cows causes a significant milk production loss
}

\author{
Piyumali K Perera ${ }^{1}$, Robin B Gasser ${ }^{1 *}$, Simon M Firestone ${ }^{1}$, Garry A Anderson ${ }^{1}$, Jakob Malmo ${ }^{1,2}$, Gerry Davis², \\ David S Beggs ${ }^{1}$ and Abdul Jabbar ${ }^{1 *}$
}

\begin{abstract}
Background: Oriental theileriosis is a tick-borne, protozoan disease of cattle caused by members of the Theileria orientalis-complex. Recent outbreaks of this disease in eastern Australia have caused major concerns to the dairy and beef farming communities, but there are no published studies of the economic impact of this disease. On a farm in Victoria, Australia, we assessed whether oriental theileriosis has an impact on milk production and reproductive performance in dairy cows.
\end{abstract}

Methods: Blood samples collected from all 662 cows on the farm were tested using an established molecular test. For individual cows, milk production and reproductive performance data were collected. A clinical assessment of individual cows was performed. Based on clinical findings and molecular test results, the following groups of cows were classified: group 1, with cardinal clinical signs of oriental theileriosis and molecular test-positive for T. orientalis; group 2, with mild or suspected signs of theileriosis and test-positive; group 3, with no clinical signs and test-positive; and group 4, with no clinical signs and test-negative. Milk production and reproductive performance data for groups 1 , 2 and 3 were each compared with those for group 4 using linear and logistic regression analyses, respectively.

Results: At 100 days of lactation, group 1 cows produced significantly less milk (288 l; $P=0.001$ ), milk fat (16.8 kg; $P<0.001)$ and milk protein $(12.6 \mathrm{~kg} ; P<0.001)$ compared with group 4 . At this lactation point, group 2 also produced significantly less milk fat ( $13.6 \mathrm{~kg} ; P=0.002)$ and milk protein $(8.6 \mathrm{~kg} ; P=0.005)$ than group 4 . At 305 days of lactation, group 1 cows produced significantly less milk (624 l; $P=0.004)$, milk fat $(42.9 \mathrm{~kg} ; P<0.001)$ and milk protein $(26.0 \mathrm{~kg}$; $P<0.001)$ compared with group 4 cows. Group 2 cows also produced significantly less milk fat $(21.2 \mathrm{~kg} ; P=0.033)$ at this lactation point. No statistically significant difference in reproductive performance was found upon pairwise comparisons of groups 1-3 with group 4 cows.

Conclusions: The present findings demonstrate that clinical oriental theileriosis can cause significant milk production losses in dairy cattle.

Keywords: Theileria orientalis, Dairy cattle, Milk production, Milk fat and protein, Australia

\section{Background}

Theileria spp. are protozoan (apicomplexan) parasites that are transmitted by ixodid ticks and cause theileriosis in animals, including domestic and wild ruminants. Theileriosis is primarily limited to tropical and subtropical regions of the world [1]. Traditionally, theileriosis caused by one or more members of the Theileria orientalis complex [2-4] was believed to have a limited impact on the

\footnotetext{
* Correspondence: robinbg@unimelb.edu.au; jabbara@unimelb.edu.au ${ }^{1}$ Faculty of Veterinary Science, The University of Melbourne, Parkville, Victoria 3010, Australia

Full list of author information is available at the end of the article
}

health of cattle in endemic regions compared with $T$. parva and T. annulata [3,5]. To date, eight distinct genotypes of $T$. orientalis (designated chitose or type 1, ikeda or type 2, buffeli or type 3 and types 4-8) have been defined using PCR-based tools [6-8]. In the Asia-Pacific region, mainly the genotypes ikeda and chitose of $T$. orientalis have been linked to clinical outbreaks of oriental theileriosis in beef and dairy cattle [9-14]. In these outbreaks, disease is usually manifested through cardinal clinical signs, such as high fever, anaemia, jaundice, lethargy, weakness, abortion and/or mortality [10-12].

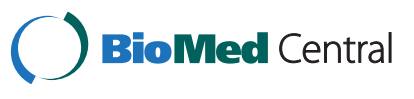


Since 2006, there have been $>500$ clinical outbreaks of this disease in cattle in Australia, mainly in the states of New South Wales and Victoria (G. Bailey and C. M. Bell, personal communication; June 2013). In Victoria alone, where more than $65 \%$ of the Australian dairy cattle occur (www.dairyaustralia.com.au), there have been $\sim 150$ outbreaks. Although recent studies [12,15-17] have provided first insights into the prevalence and distribution of $T$. orientalis infection, nothing is known about the economic impact associated with the clinical form of oriental theileriosis in affected regions of Australia. The present study assessed the impact of oriental theileriosis on milk production and reproductive performance of cows on a dairy farm in Victoria, Australia.

\section{Methods}

\section{Study site and cattle}

The present study was conducted on a closed dairy cattle farm (latitude $37^{\circ} 54$ ' $\mathrm{S}$, longitude $146^{\circ} 51^{\prime} \mathrm{E}$ ) in Maffra, East Gippsland, Victoria, Australia. Between 31 October 2012 and 1 December 2012, the average minimum and maximum environmental temperatures were $10.4^{\circ} \mathrm{C}$ and $22.4^{\circ} \mathrm{C}$, respectively, and the highest rainfall was $19 \mathrm{~mm}$ (www.bom.gov.au). Included in this study were 662 cows maintained on pastures; most of them $(n=321)$ were Jersey $\mathrm{x}$ Friesian, and 99 Friesian, 10 Jersey and 173 were various dairy crossbreeds (Table 1). Cows were 2 to 14 years of age, with $51 \%$ being $3-5$ years (Table 1); they calved from late July to early October each year. All cows were vaccinated as calves (up to one year) against clostridial disease (caused by Clostridium perfringens type D, C. tetani, C. novyi type B, C. septicum and C. chauvoei) and leptospirosis (caused by Leptospira hardjo and L. pomona), and were given a booster vaccination each year.

Cows were milked twice daily (5.30 a.m. and 3 p.m.). They grazed primarily on irrigated pastures and were also given $4 \mathrm{~kg}$ of feed supplement (i.e., primarily cracked wheat, corn and/or canola, together with pellets containing a mixture of minerals and monensin) per cow per day, equating to $\sim 1.2$ tonnes per cow per annum. A computer system (Dairy Data for Windows) was used to maintain records of milk yield, milk composition and somatic cell counts [18]. Data were obtained from herd tests performed on individual cows, every 2-3 weeks for the first 9 weeks following calving, and then bi-monthly for the remainder of the lactation); calving and mating dates for individual cows were also recorded. The results of pregnancy testing were also entered into this system, allowing a detailed evaluation of the reproductive performance of all animals in the herd.

\section{Clinical assessment of cows, and collection of blood samples} The clinical assessment of individual cows in the present study site was undertaken and/or supervised by a registered, specialist cattle veterinarian (J. M.), who has been practising for $>50$ years. The cardinal signs recorded for a clinical diagnosis of oriental theileriosis were pale vulval mucous membrane, anorexia, lethargy and increased heart ( $\geq 76$ beats per minute) and respiratory rates (numbers per minute) [10]. Mild or suspected theileriosis was inferred clinically based on pale vulval mucous membrane, weight loss and lethargy. During the entire study period, there was no clinical evidence of any other infectious diseases (including mastitis) other than oriental theileriosis on the farm; cattle on this farm were routinely monitored for mastitis.

Blood samples were collected from cows from the coccygeal vein (using an 18 gauge needle) into EDTA tubes by registered, practicing veterinarians (J. M. and G. D.). The packed cell volume (PCV) of individual samples was determined [17]. In November 2012, samples were collected from all 662 cows (first sampling). In March 2013, samples were collected from a subset of 220 cows (second sampling); this latter number was calculated based on the estimated prevalence of theileriosis, determined following the molecular testing of all 662 cows using a confidence of $95 \%$ and a desired absolute precision of $6.5 \%$ [19].

\section{Molecular testing for $T$. orientalis}

Genomic DNAs were extracted from individual blood samples using the DNeasy blood and tissue kit (cat. no. 69506, Qiagen, USA) following the manufacturer's protocol. A portion (344 bp) of the major piroplasm surface protein (MPSP) gene was amplified by PCR from genomic DNA using the primer pair mpsp-AJ-F and mpsp-AJ-R1 [15]. In addition, for some of the samples from second blood sampling, a portion (776 bp) of the small subunit of nuclear ribosomal RNA (SSU $r R N A$ ) gene was amplified by PCR from genomic DNA using the primer pair SSU-F

Table 1 Age and breed of the cows studied on a closed dairy farm in Maffra, Victoria

\begin{tabular}{|c|c|c|c|c|c|c|c|c|c|c|}
\hline \multirow[t]{2}{*}{ Bleed } & \multirow[t]{2}{*}{$\begin{array}{l}\text { Date of } \\
\text { collection }\end{array}$} & \multirow[t]{2}{*}{$\begin{array}{l}\text { Number } \\
\text { of cows bled }\end{array}$} & \multirow[t]{2}{*}{$\begin{array}{l}\text { Number of cows with } \\
\text { demographic data }\end{array}$} & \multicolumn{3}{|c|}{$\begin{array}{c}\text { Age (years) } \\
\% \text { (proportion) }\end{array}$} & \multicolumn{4}{|c|}{$\begin{array}{c}\text { Breed } \\
\% \text { (proportion) }\end{array}$} \\
\hline & & & & $\leq 2$ & $3-5$ & $\geq 6$ & Jersey $\times$ Friesian & Friesian & Jersey & Other cross-bred \\
\hline 1 & $\begin{array}{l}\text { November } \\
2012\end{array}$ & 662 & 603 & $\begin{array}{l}16.8 \\
(101 / 603)\end{array}$ & $\begin{array}{l}51.2 \\
(309 / 603)\end{array}$ & $\begin{array}{l}32.0 \\
(193 / 603)\end{array}$ & $\begin{array}{l}53.2 \\
(321 / 603)\end{array}$ & $\begin{array}{l}16.4 \\
(99 / 603)\end{array}$ & $\begin{array}{l}1.7 \\
(10 / 603)\end{array}$ & $\begin{array}{l}28.7 \\
(173 / 603)\end{array}$ \\
\hline 2 & $\begin{array}{l}\text { March } \\
2013\end{array}$ & 220 & 189 & $\begin{array}{l}18.5 \\
(35 / 189)\end{array}$ & $\begin{array}{l}51.3 \\
(97 / 189)\end{array}$ & $\begin{array}{l}30.2 \\
(57 / 189)\end{array}$ & $\begin{array}{l}53.4 \\
(101 / 189)\end{array}$ & $\begin{array}{l}17.5 \\
(33 / 189)\end{array}$ & $\begin{array}{l}1.6 \\
(3 / 189)\end{array}$ & $\begin{array}{l}27.5 \\
(52 / 189)\end{array}$ \\
\hline
\end{tabular}


and SSU-R [12]. For each set of PCRs, negative (no-DNA) and known positive controls (T. orientalis) were included. Following PCR, $5 \mu \mathrm{l}$ of each amplicon were examined on $1.5 \% \mathrm{w} / \mathrm{v}$ agarose gels, which were stained with ethidium bromide and then photographed (GelDoc, BioRad). All samples that tested negative were retested after diluting genomic DNAs (1:10) in water, as described previously [17], to exclude inhibition in PCR by blood constituents. In order to display sequence variation within and among amplicons, single-strand conformation polymorphism (SSCP) analysis [20] was employed as described previously $[15,17]$. Aliquots of amplicons $(n=1-5)$ representing each unique SSCP profile were taken, treated with shrimp alkaline phosphatase and exonuclease I (Fermentas Inc., USA) [21] and then subjected to bi-directional, automated sequencing (BigDye ${ }^{\circledR}$ Terminator v.3.1, Applied Biosystems, USA) using (separately) the same primers employed in PCR. Amplicons representing an SSCP profile inferred to be a composite of other profiles were individually cloned and then sequenced using an established protocol [15] to determine the genotypes present. The quality of individual sequences was assessed using the program Geneious Pro 5.6.5 (Biomatters Ltd., Auckland, New Zealand), aligned using Clustal X 2.0.10 [22] and subjected to BLASTn analysis (http://blast.ncbi.nlm.nih.gov) to establish the best matches to nucleotide sequences available in the GenBank database.

\section{Classification of four groups of cows}

Based on clinical findings and molecular test results, the following groups of cows were classified: group 1, with cardinal clinical signs of oriental theileriosis (see clinical assessment) and molecular test-positive for T. orientalis; group 2, with mild or suspected signs of theileriosis and test-positive for $T$. orientalis; group 3, with no clinical signs (subclinical) and test-positive for T. orientalis; and group 4, with no clinical signs and test-negative for T. orientalis.

\section{Collection of data on milk production and reproduction, and analyses}

For individual cows, milk production was assessed. Specifically, milk volume (in l), milk fat $(\mathrm{kg})$, milk protein $(\mathrm{kg})$ and milk solids (kg; milk fat plus milk protein) were measured for the majority of the herd, every 2-3 weeks for the first 9 weeks following calving, bi-monthly for the remainder of the lactation, and then calculated for 100 and 305 days of lactation. Milk production data for groups 1, 2 and 3 at 100 days and 305 days of lactation were each compared with those for group 4. Linear regression analysis was conducted using statistical software IBM SPSS Statistics 22. To remove the confounding effect of age on the results, milk production data were adjusted according to age category ( $\leq 2$ years, $3-5$ years or $\geq 6$ years of age).
A $P$-value of $<0.05$ was considered as statistically significant. The losses caused by a reduction in milk production were calculated in Australian (AUD) or US (USD) dollars, according to current milk prices (i.e., 32.4 cents per litre) published in September 2012 by the Dairy Farmers Milk Cooperative, Australia.

For individual cows, reproductive performance was also monitored and evaluated. Specifically, submission rate by 21 days (SR21d), first service conception rate (CR1), incalf by 6 weeks (ICR6w), in-calf by 14 weeks (ICR14w) and not in-calf at 21 weeks (NIC21w) were calculated. Pairwise comparisons were made between cow groups $1-3$ and group 4 (= negative reference), and logistic regression analysis was conducted using IBM SPSS Statistics 22. All data were adjusted according to cow age category to remove any possible confounding effect of age on the results. Additionally, CR1 was adjusted for the calving-to-service interval (CS1) and CS1 squared (CS1sq). In addition to age categories, ICR6w, ICR14w, NIC21w and SR21d were adjusted for the calving-tomating start date (CMSD) interval and CMSD squared (CMSDsq) [23]. A $P$-value of $<0.05$ was considered as statistically significant.

\section{Results}

\section{Molecular identification of $T$. orientalis}

Bloods from the first sampling (November 2012) were tested. Amplicons (partial MPSP) of the expected size (344 bp) were produced from $45.5 \%$ of the 662 blood DNA samples (Table 2). Based on SSCP analysis of all 301 amplicons, three distinct profiles were recorded; the profiles 1, 2 and 3 represented 294, 5 and 2 of the 301 samples, respectively (Table 2). Aliquots of multiple (3-5) amplicons representing each of the profiles 1-3 were sequenced. The sequences of all amplicons representing each profiles 1 and 2 represented $T$. orientalis genotypes ikeda and chitose, respectively, based on comparisons with reference sequences [GenBank: JQ781071, JQ781070, KC915202, KC915200]. Profile 3 represented a mix of profiles 1 and 2 (cf. [15,17]) and, consequently, was a mix of the profiles representing genotypes ikeda and chitose (Table 2). Therefore, the dominant genotype in all cows was ikeda (97.7\%), followed by chitose $(1.7 \%)$ (Table 2).

To assess whether there was a change in the percentage of cows with $T$. orientalis infection in the period from November 2012 to March 2013, blood samples $(n=220)$ from the second sampling were tested molecularly and compared with molecular test results for the first sampling. Of 220 samples, 92 were test-positive for T. orientalis (Table 2), and genotypes ikeda and chitose were detected in 91 and 1 of the 92 samples, respectively; only one cow that was test-negative for $T$. orientalis in the first sampling was test-positive in the second. Similarly, 
Table 2 A summary of molecular test results and genotypes of $T$. orientalis detected in cows

\begin{tabular}{|c|c|c|c|c|c|}
\hline \multicolumn{3}{|l|}{ Bleed 1} & \multicolumn{3}{|l|}{ Bleed 2} \\
\hline $\begin{array}{l}\text { Molecular test } \\
\text { result }\end{array}$ & $\begin{array}{l}\text { Proportion of } \\
\text { cows }(\%)\end{array}$ & $\begin{array}{l}\text { Genotype(s) detected } \\
\text { (\%; proportion) }\end{array}$ & $\begin{array}{l}\text { Molecular test } \\
\text { result }\end{array}$ & $\begin{array}{l}\text { Proportion of } \\
\text { cows }(\%)\end{array}$ & $\begin{array}{l}\text { Genotype(s) detected } \\
\text { (\%; proportion) }\end{array}$ \\
\hline \multirow[t]{2}{*}{ Negative } & $361 / 662(54.5 \%)$ & & Negative & 123/124 (99.2) & \\
\hline & & & Positive & $1 / 124(0.8)$ & Ikeda $(1.1 ; 1 / 92)$ \\
\hline \multirow[t]{4}{*}{ Positive } & $301 / 662$ (45.5\%) & Ikeda (97.7; 294/301) & Negative & $5 / 96(5.2)$ & \\
\hline & & & Positive & 91/96 (94.8) & $\begin{array}{l}\text { Ikeda }(97.8 ; 90 / 92) ; \text { Chitose }(1.1 ; 1 / 92) ; \\
\text { Mixed infection of ikeda and chitose (0; 0/92) }\end{array}$ \\
\hline & & Chitose $(1.7 ; 5 / 301)$ & & & \\
\hline & & $\begin{array}{l}\text { Mixed infection of ikeda } \\
\text { and chitose }(0.6 ; 2 / 301)\end{array}$ & & & \\
\hline
\end{tabular}

'Positive' denotes that the blood DNA samples were fully characterised by PCR and sequencing and were found to be test-positive for $T$. orientalis.

five cows that were test-positive in the first sampling were test-negative in the second (Table 2). For one cow, genotype ikeda was identified in the first sampling and genotype chitose (but not ikeda) in the second. Conversely, for another cow, genotype chitose was identified in the first sampling and genotype ikeda (but not chitose) in the second. This "switch" in genotype was confirmed by PCRbased DNA sequencing of both MPSP and SSU genes (data not shown).

\section{Haematocrit values}

An analysis of 603 blood samples (i.e., blood samples from all 603 cows with demographic data) from the first sampling showed that PCVs were significantly lower for group $1(P<0.001)$ and group $2(P<0.001)$ compared with group 4 cows. However, PCV for group 3 was not significantly lower $(P=0.087)$ compared with group 4 (Table 3$)$.

\section{Production losses}

Based on clinical signs and molecular test results (November 2012), group 1 comprised 16 diseased cows infected and affected by the genotype ikeda; group 2 consisted of 13 and one cows that were infected and mildly affected by genotypes ikeda and chitose, respectively; group 3 comprised 238 and four asymptomatic cows harbouring genotypes ikeda and chitose, respectively, and two other asymptomatic cows both harboured ikeda $\mathcal{E}$ chitose; group 4 comprised 309 asymptomatic cows with no evidence from molecular testing of $T$. orientalis infection. At 100 and 305 days of lactation, milk production data from cow groups 1-3 were compared (in a pairwise manner) with those from group 4. At 305 days, the numbers of cows in groups 1, 3 and 4 reduced slightly to 13, 221 and 289, respectively, since the rest of the cows had "dried-off" or were sold.

Analyses showed that, at 100 days of lactation, group 1 cows produced significantly less milk (288 l; $P=0.001)$ (Table 4), milk fat $(16.8 \mathrm{~kg} ; P<0.001)$ (Table 5) and milk protein $(12.6 \mathrm{~kg} ; P<0.001)$ than those in group 4 (Table 6). Group 2 cows also produced significantly less milk fat (13.6 kg; $P=0.002$ ) (Table 5) and milk protein (8.6 kg; $P=0.005)$ than group 4 cows at this lactation point (Table 6).

Analyses also showed that, at 305 days of lactation, group 1 cows produced significantly less milk (624 l; $P=$ 0.004) (Table 4), milk fat $(42.9 \mathrm{~kg} ; P<0.001)$ (Table 5) and

Table 3 A comparison of packed cell volume (PCV) (in \%) among different categories of dairy cows

\begin{tabular}{|c|c|c|c|c|}
\hline \multirow[t]{2}{*}{ Variable } & \multicolumn{4}{|l|}{ PCV } \\
\hline & Group (n) & Mean difference ${ }^{a}$ (Standard error) & $95 \%$ Confidence interval $^{a}$ & $P$-value ${ }^{a}$ \\
\hline \multirow[t]{4}{*}{ Clinical and molecular test results } & $1(16)$ & $-14.36(0.78)$ & $-15.88,-12.83$ & $<0.001$ \\
\hline & $2(14)$ & $-4.48(0.83)$ & $-6.11,-2.86$ & $<0.001$ \\
\hline & $3(254)$ & $0.45(0.26)$ & $-0.06,0.96$ & 0.087 \\
\hline & $4(319)$ & Reference group & & \\
\hline \multirow[t]{3}{*}{ Age (years) } & $\geq 6(193)$ & $1.77(0.39)$ & $1.02,2.52$ & $<0.001$ \\
\hline & $3-5(309)$ & $1.93(0.35)$ & $1.24,2.62$ & $<0.001$ \\
\hline & $\leq 2(101)$ & Reference group & & \\
\hline
\end{tabular}

Intercept for PCV was $24.9 \%$.

${ }^{a}$ Mean difference was adjusted for three age categories (i.e., two years, three to five years, and six years and above).

Group 1, with cardinal clinical signs of oriental theileriosis \& molecular test-positive for $T$. orientalis; group 2, with mild or suspected signs of theileriosis \& testpositive for $T$. orientalis; group 3, with no clinical signs \& test-positive for $T$. orientalis; and group 4, with no clinical signs \& test-negative for $T$. orientalis.

$P$-values were obtained by comparing each category with the reference group. 
Table 4 A comparison of milk volume (I) among different categories of dairy cows

\begin{tabular}{|c|c|c|c|c|c|c|c|c|}
\hline \multirow[t]{2}{*}{ Variable } & \multirow[b]{2}{*}{ Group $(n)^{a}$} & \multicolumn{3}{|c|}{ Milk volume at 100 days of lactation } & \multirow[b]{2}{*}{ Group $(n)^{a}$} & \multicolumn{3}{|c|}{ Milk volume at 305 days of lactation } \\
\hline & & $\begin{array}{l}\text { Mean difference }{ }^{\mathbf{b}} \\
\text { (Standard error) }\end{array}$ & $\begin{array}{l}\text { 95\% Confidence } \\
\text { interval }^{\mathrm{b}}\end{array}$ & $P$-value ${ }^{\mathrm{b}}$ & & $\begin{array}{l}\text { Mean difference }{ }^{b} \\
\text { (Standard error) }\end{array}$ & $\begin{array}{l}\text { 95\% Confidence } \\
\text { interval }^{\mathbf{b}}\end{array}$ & $P$-value ${ }^{b}$ \\
\hline \multirow{4}{*}{$\begin{array}{l}\text { Clinical and molecular } \\
\text { test results }\end{array}$} & $1(16)$ & $-288(90.4)$ & $-465.7,-111.2$ & 0.001 & $1(13)$ & $-624(216.9)$ & $-1048.7,-198.6$ & 0.004 \\
\hline & $2(14)$ & $-153(95.9)$ & $-341.0,35.0$ & 0.11 & $2(14)$ & $-115(208.6)$ & $-523.7,293.9$ & 0.58 \\
\hline & $3(244)$ & $11(30.7)$ & $-48.9,71.4$ & 0.72 & $3(221)$ & $82(69.7)$ & $-55.0,218.1$ & 0.24 \\
\hline & $4(309)$ & Reference group & & & $4(289)$ & Reference group & & \\
\hline \multirow[t]{3}{*}{ Age (years) } & $\geq 6(184)$ & $595(45.1)$ & $506.4,683.3$ & $<0.001$ & $\geq 6(158)$ & $1160(101.3)$ & $961.6,1358.6$ & $<0.001$ \\
\hline & $3-5(302)$ & $484(41.6)$ & $402.3,565.4$ & $<0.001$ & $3-5(283)$ & $867(91.3)$ & $688.0,1046.0$ & $<0.001$ \\
\hline & $\leq 2(97)$ & Reference group & & & $\leq 2(96)$ & Reference group & & \\
\hline
\end{tabular}

Intercepts for milk volumes produced at 100 and 305 days of lactation were $1860 \mathrm{I}$ and $4600 \mathrm{I}$, respectively.

aNumbers of cows differed, because some cows "dried off" or were sold.

${ }^{b}$ Mean difference was adjusted for three age categories (i.e., two years or less, three to five years, and six years or more).

Group 1, with cardinal clinical signs of oriental theileriosis \& molecular test-positive for $T$. orientalis; group 2, with mild or suspected signs of theileriosis \& test-

positive for T. orientalis; group 3, with no clinical signs \& test-positive for T. orientalis; and group 4, with no clinical signs \& test-negative for T. orientalis.

$P$-values were obtained by comparing each category with the reference group.

milk protein $(26.0 \mathrm{~kg} ; P<0.001)$ compared with group 4 cows (Table 6). Group 2 cows also produced significantly less milk fat (21.2 kg; $P=0.033)$ (Table 5) at this lactation point. However, no significant difference in milk production was found between group 3 and group 4 cows at both 100 and 305 days of lactation (Tables 4, 5 and 6). In contrast to the significant decrease in milk production observed for groups 1 and 2, no statistically significant difference in reproductive performance was found upon pairwise comparisons of groups 1-3 with group 4 cows (Additional file 1: Table S1 and Additional file 2: Table S2).

\section{Discussion}

The present findings showed that, while reproduction was not significantly affected, dairy cows suffering from clinically severe oriental theileriosis (group 1) produced 6241 less milk per head at 305 days of lactation, leading to an estimated annual economic loss of AUD 202 (USD
179) per head. The loss caused by the death of a single cow was AUD 1,800. Therefore, on the farm studied here, the total economic loss associated with 16 severely affected cows and one dead cow was estimated at AUD 5,035 in the first year. Although not statistically significant, the reduction in milk production in the 14 cows inferred to be mildly affected by $T$. orientalis infection was $115 \mathrm{l}$ per head at 305 days of lactation, which suggests that a further AUD 522 may have been lost. Although the mortality rate due to oriental theileriosis was low in the present study, rates as high as $11 \%$ have been recorded in the state of Victoria, Australia (J. M., personal communication; December 2013). This loss is proposed to be much less in subsequent years due to an apparent "stabilisation" of the infection or immunity of the herd. From the current study, it is apparent that molecular testing is critical to assessing the status of oriental theileriosis in herds.

Table 5 A comparison of milk fat $(\mathbf{k g})$ among different categories of dairy cows

\begin{tabular}{|c|c|c|c|c|c|c|c|c|}
\hline \multirow[t]{2}{*}{ Variable } & \multirow[b]{2}{*}{ Group $(n)^{\mathrm{a}}$} & \multicolumn{3}{|c|}{ Milk fat at 100 days of lactation } & \multirow[b]{2}{*}{ Group $(n)^{\mathrm{a}}$} & \multicolumn{3}{|c|}{ Milk fat at 305 days of lactation } \\
\hline & & $\begin{array}{l}\text { Mean difference } \\
\text { (Standard error) }\end{array}$ & $\begin{array}{l}\text { 95\% Confidence } \\
\text { interval }^{\mathrm{b}}\end{array}$ & $P$-value ${ }^{b}$ & & $\begin{array}{l}\text { Mean difference } \\
\text { (Standard error) }\end{array}$ & $\begin{array}{l}95 \% \text { Confidence } \\
\text { interval }^{\mathrm{b}}\end{array}$ & $P$-value ${ }^{b}$ \\
\hline \multirow{4}{*}{$\begin{array}{l}\text { Clinical and molecular } \\
\text { test results }\end{array}$} & $1(16)$ & $-16.8(4.2)$ & $-25.0,-8.6$ & $<0.001$ & $1(13)$ & $-42.9(10.4)$ & $-63.2,-22.6$ & $<0.001$ \\
\hline & $2(14)$ & $-13.6(4.4)$ & $-22.3,-4.9$ & 0.002 & $2(14)$ & $-21.2(10.0)$ & $-40.7,-1.7$ & 0.033 \\
\hline & $3(244)$ & $1.0(1.4)$ & $-1.8,3.7$ & 0.50 & $3(221)$ & $2.2(3.3)$ & $-4.4,8.7$ & 0.51 \\
\hline & 4 (309) & Reference group & & & 4 (289) & Reference group & & \\
\hline \multirow[t]{3}{*}{ Age (years) } & $\geq 6(184)$ & $23.0(2.1)$ & $18.9,27.1$ & $<0.001$ & $\geq 6(158)$ & $49.3(4.8)$ & $39.8,58.8$ & $<0.001$ \\
\hline & $3-5(302)$ & $17.8(1.9)$ & $14.0,21.6$ & $<0.001$ & $3-5(283)$ & $37.6(4.4)$ & $29.0,46.1$ & $<0.001$ \\
\hline & $\leq 2(97)$ & Reference group & & & $\leq 2(96)$ & Reference group & & \\
\hline
\end{tabular}

Intercepts for milk fat produced at 100 and 305 days of lactation were $79.0 \mathrm{~kg}$ and $213.3 \mathrm{~kg}$, respectively.

aNumbers of cows differed because some cows "dried off" or were sold.

${ }^{b}$ Mean difference was adjusted for three age categories (i.e., two years or less, three to five years, and six years or more).

Group 1, with cardinal clinical signs of oriental theileriosis \& molecular test-positive for $T$. orientalis; group 2, with mild or suspected signs of theileriosis \& testpositive for T. orientalis; group 3, with no clinical signs \& test-positive for $T$. orientalis; and group 4, with no clinical signs \& test-negative for $T$. orientalis.

$P$-values were obtained by comparing each category with the reference group. 
Table 6 A comparison of milk protein $(\mathbf{k g})$ among different categories of dairy cows

\begin{tabular}{|c|c|c|c|c|c|c|c|c|}
\hline \multirow[t]{2}{*}{ Variable } & \multirow[b]{2}{*}{ Group $(n)^{\mathrm{a}}$} & \multicolumn{3}{|c|}{ Milk protein at 100 days of lactation } & \multirow[b]{2}{*}{ Group $(n)^{\mathrm{a}}$} & \multicolumn{3}{|c|}{ Milk protein at 305 days of lactation } \\
\hline & & $\begin{array}{l}\text { Mean difference }{ }^{\mathbf{b}} \\
\text { (Standard error) }\end{array}$ & $\begin{array}{l}\text { 95\% Confidence } \\
\text { interval }^{\mathrm{b}}\end{array}$ & $P$-value ${ }^{\mathrm{b}}$ & & $\begin{array}{l}\text { Mean difference }{ }^{b} \\
\text { (Standard error) }\end{array}$ & $\begin{array}{l}\text { 95\% Confidence } \\
\text { interval }^{\mathbf{b}}\end{array}$ & $P$-value ${ }^{b}$ \\
\hline \multirow{4}{*}{$\begin{array}{l}\text { Clinical and molecular } \\
\text { test results }\end{array}$} & $1(16)$ & $-12.6(2.9)$ & $-18.2,-7.0$ & $<0.001$ & $1(15)$ & $-26.0(7.0)$ & $-39.7,-12.3$ & $<0.001$ \\
\hline & $2(14)$ & $-8.6(3.0)$ & $-14.5,-2.7$ & 0.005 & $2(14)$ & $-11.1(6.7)$ & $-24.3,2.1$ & 0.099 \\
\hline & $3(244)$ & $0.30(1.0)$ & $-1.6,2.2$ & 0.76 & $3(219)$ & $2.9(2.2)$ & $-1.5,7.3$ & 0.20 \\
\hline & $4(309)$ & Reference group & & & $4(289)$ & Reference group & & \\
\hline \multirow[t]{3}{*}{ Age (years) } & $\geq 6(184)$ & $20.7(1.4)$ & $18.0,23.5$ & $<0.001$ & $\geq 6(158)$ & $39.6(3.3)$ & $33.2,46.0$ & $<0.001$ \\
\hline & $3-5(302)$ & $17.2(1.3)$ & $14.6,19.8$ & $<0.001$ & $3-5(283)$ & $31.6(2.9)$ & $25.8,37.4$ & $<0.001$ \\
\hline & $\leq 2(97)$ & Reference group & & & $\leq 2(96)$ & Reference group & & \\
\hline
\end{tabular}

Intercepts for milk protein produced at 100 and 305 days of lactation were $61.5 \mathrm{~kg}$ and $160.0 \mathrm{~kg}$, respectively.

a Numbers of cows differed, because some cows "dried off" or were sold.

${ }^{\mathrm{b}}$ Mean difference was adjusted for three age categories (i.e., two years or less, three to five years, and six years or more).

Group 1, with cardinal clinical signs of oriental theileriosis \& molecular test-positive for $T$. orientalis; group 2, with mild or suspected signs of theileriosis \& test-

positive for $T$. orientalis; group 3, with no clinical signs \& test-positive for T. orientalis; and group 4, with no clinical signs \& test-negative for $T$. orientalis.

$P$-values were obtained by comparing each category with the reference group.

Previously, no information was available on the production losses associated with clinical form of oriental theileriosis for any part of the world, including Australia, in which numerous outbreaks have occurred in the past two years. Nonetheless, production losses linked to other species of Theileria in bovines, such as T. parva, have been recorded in Kenya [24,25] and in Tanzania [26-28]. In addition, production losses and mortality rates associated with theileriosis caused by $T$. annulata have been reported from Turkey [29].

In Australia in 1997, economic losses caused by ticks and tick-borne diseases in cattle were reported to cost USD 7.8 per head [30], which is likely to be considerably higher today. In 1999, tick fever caused by Babesia bovis, Babesia bigemina and/or Anaplasma marginale cost the beef industry in northern Australia AUD 27 million [31]. The annual cost per head caused by oriental theileriosis is likely to be significant, and seems to be similar to the annual cost of AUD 227 per head due to T. parva in Tanzania [28]. However, there is a limitation in comparing studies, because the present study was based on both clinical diagnosis and molecular identification of the parasite, while the study by Kivaria et al. [28] relied on clinical signs and microscopy for the diagnosis of theileriosis. In addition, the economic losses estimated by these authors [28] were calculated by adding the costs of milk loss, weight loss, acaricidal treatment and immunisation [28], but the present study considered only the loss in milk production. However, if the cost of tick control were included here, the total loss per head due to oriental theileriosis would likely to be considerably higher.

In the present study, we found that the clinical outbreak was linked mainly to a high (97.7\%) and low (1.7\%) prevalence of the virulent genotypes, ikeda and chitose, of $T$. orientalis, respectively. Sequences representing these two genotypes were the same as those [GenBank: JQ781071,
JQ781070, KC915200, KC915202] characterised previously for T. orientalis from cattle in Victoria [15,17]. Although the genotype buffeli of $T$. orientalis is suspected to be endemic to some parts of Gippsland region (C. M. Bell, unpublished data), we did not detect this genotype herein using the present molecular approach. The high prevalence of genotype ikeda in cows on the present 'closed' dairy farm may have occurred as a consequence of cattle movement to nearby properties (during the dry period) from other regions in Victoria, where this genotype is prevalent. In addition, this might relate to a dominance of the virulent genotype populations over 'benign' types of $T$. orientalis [16].

Genotypes found in the bloods of individual cows did not alter from the first to second sampling, except for two cows. However, changes in a dominant parasite population have been reported to occur during the transmission from calves to ticks and from infected ticks to calves [32]. Changes in ikeda and chitose populations might also relate to host immune pressure on the parasite during persistent infection over several months [32]. Although this evidence might explain a possible genotypic switch, further, detailed investigations are required to establish whether genotypic alterations do actually occur within a period as short as three months (as in the present study).

Here, the number of cows with $T$. orientalis infection in the herd was relatively stable; five test-positive cows became test-negative, and one test-negative cow became test-positive within the study period of three-months. Previously, a study by Shimizu et al. [33] also showed that new infections $(87.5 \%$ of 8$)$ by $T$. orientalis occurred within a period of two months. However, there are limitations in comparing the present study with that of Shimizu et al. [33], as the latter authors used ELISA for the indirect detection of infection (through serum 
antibody), whereas we used a more sensitive method (PCR-based mutation scanning and selective sequencing) for the direct detection of parasite DNA. Similar to the findings of the present study, Ota et al. [8] reported that the prevalence of $T$. orientalis infection increased from $2.2 \%$ of 89 to up to $48.4 \%$ of 91 by three weeks, and up to $64.8 \%$ of 91 cattle (various breeds) by two months, based on testing by PCR and sequencing of two loci (i.e., MPSP and $p 23$ ). These authors [8] suggested that the possible reason for new infections could be the seasonal activity of the infected tick vector. In the present study, new $T$. orientalis infections could have occurred as a result of tick transmission from other infected cows in the herd; however, the role of ticks in the transmission of oriental theileriosis in Victoria remains enigmatic and requires detailed study.

\section{Conclusions}

Although economic losses associated with oriental theileriosis appear to have been ignored in the past, the present findings clearly show that clinical oriental theileriosis can cause significant milk production losses in dairy cattle. Future investigations should focus on assessing the economic impact of this disease on a much larger scale in eastern Australia. In the meantime, efforts should focus on improving the management and control of oriental theileriosis to subvert the impact of this disease on the dairy industry in Australia.

\section{Additional files}

Additional file 1: Table S1. A comparison of reproduction indices among different categories of dairy cows.

Additional file 2: Table S2. A comparison of reproduction indices among different categories of dairy cows.

\section{Abbreviations \\ CMSD: Calving-to-mating start date; CMSDsq: Calving-to-MSD squared; CR1: First service conception rate; CS1: Calving-to-service interval; CS1 sq: CS1 squared; ICR6w: In-Calf by 6 weeks; ICR14w: In-Calf by 14 weeks; MPSP: Major piroplasm surface protein; PCV: Packed cell volume; NIC21w: Not In-Calf at 21 weeks; SSU rRNA: Small subunit of nuclear ribosomal RNA; SR21d: Submission rate by 21 days.}

\section{Competing interests}

The authors declare that they have no competing interests.

\section{Authors' contributions}

PP carried out the PCR-based analysis, data analyses, interpretation of data and also drafted the manuscript, with guidance from co-authors. JM and GD undertook clinical examinations of cows and participated in the study design. DSB and JM provided milk production data. JM and GD collected blood samples and determined PCVs. SMF, GAA and PP performed the statistical analyses. AJ, RBG and JM conceived the project, participated in the study design, interpreted the data and provided critical inputs on the draft manuscript. All authors read and approved the final manuscript.

\section{Acknowledgements}

This project was partially supported by Dairy Australia, a Collaborative Research Grant (the University of Melbourne), the Department of Agriculture,
Fisheries and Forestry (DAFF) (A. J.) and the Australian Research Council (ARC) (R. B. G.). P. P. is a grateful recipient of the International Postgraduate Research Scholarship (IPRS) and Australian Postgraduate Award (APA) through The University of Melbourne.

\section{Author details}

${ }^{1}$ Faculty of Veterinary Science, The University of Melbourne, Parkville, Victoria 3010, Australia. ${ }^{2}$ Maffra Veterinary Centre, Maffra, Victoria 3860, Australia.

Received: 12 January 2014 Accepted: 10 February 2014

Published: 19 February 2014

\section{References}

1. Uilenberg G: International collaborative research: significance of tickborne hemoparasitic diseases to world animal health. Vet Parasitol 1995, 57:19-41.

2. Uilenberg G, Mpangala C, McGregor W, Callow LL: Biological differences between African Theileria mutans (Theiler 1906) and two benign species of Theileria of cattle in Australia and Britain. Aust Vet J 1977, 53:271-273.

3. Uilenberg G: Theilerial species of domestic livestock. In Advances in the Control of Theileriosis. Edited by Irvin AD, Cunninham MP, Young AS. Hage. The Netherlands: Martinus Nijhoff Publishers; 1981:4-37.

4. Jongejan F, Musisi FL, Moorhouse PD, Snacken M, Uilenberg G: Theileria taurotragi in Zambia. Vet Q 1986, 8:261-263.

5. Yokoyama N, Ueno A, Mizuno D, Kuboki N, Khukhuu A, Igarashi I, Miyahara T, Shiraishi T, Kudo R, Oshiro M, Zakimi S, Sugimoto C, Matsumoto K, Inokuma H: Genotype diversity of Theileria orientalis detected from cattle grazing in Kumamoto and Okinawa prefectures of Japan. J Vet Med Sci 2011, 73:305-312.

6. Kakuda T, Shiki M, Kubota S, Sugimoto C, Brown WC, Kosum C, Nopporn S, Onuma M: Phylogeny of benign Theileria species from cattle in Thailand, China and the U.S.A. based on the major piroplasm surface protein and small subunit ribosomal RNA genes. Int J Parasitol 1998, 28:1261-1267.

7. Gubbels MJ, Hong Y, van der Weide M, Qi B, Nijman IJ, Guangyuan L, Jongejan F: Molecular characterisation of the Theileria buffeli/orientalis group. Int J Parasitol 2000, 30:943-952.

8. Ota N, Mizuno D, Kuboki N, Igarashi I, Nakamura Y, Yamashina H, Hanzaike T, Fujii K, Onoe S, Hata H, Kondo S, Matsui S, Koga M, Matsumoto K, Inokuma $\mathrm{H}$, Yokoyama N: Epidemiological survey of Theileria orientalis infection in grazing cattle in the eastern part of Hokkaido, Japan. $J$ Vet Med Sci 2009, 71:937-944.

9. Sugimoto C, Fujisaki K: Non-transforming Theileria parasites of ruminants In Theileria. Edited by Dobbelaere DAE, McKeever DJ. Dordrecht. The Netherlands: Kluwer Academic Publishers Group; 2002:93-106.

10. Izzo MM, Poe I, Horadagoda N, De Vos AJ, House JK: Haemolytic anaemia in cattle in NSW associated with Theileria infections. Aust Vet J 2010, 88:45-51.

11. Aparna M, Ravindran $R$, Vimalkumar MB, Lakshmanan B, Rameshkumar $P$, Kumar KG, Promod K, Ajithkumar S, Ravishankar C, Devada K, Subramanian $\mathrm{H}$, George AJ, Ghosh S: Molecular characterization of Theileria orientalis causing fatal infection in crossbred adult bovines of South India. Parasitol Int 2011, 60:524-529.

12. Islam MK, Jabbar A, Campbell BE, Cantacessi C, Gasser RB: Bovine theileriosis-an emerging problem in south-eastern Australia? Infect Genet Evol 2011, 11:2095-2097.

13. McFadden AM, Rawdon TG, Meyer J, Makin J, Morley CM, Clough RR, Tham K, Mullner P, Geysen D: An outbreak of haemolytic anaemia associated with infection of Theileria orientalis in naive cattle. N Z Vet J 2011, 59:79-85.

14. Kamau J, de Vos AJ, Playford M, Salim B, Kinyanjui P, Sugimoto C: Emergence of new types of Theileria orientalis in Australian cattle and possible cause of theileriosis outbreaks. Parasit Vectors 2011, 4:22.

15. Cufos N, Jabbar A, de Carvalho LM, Gasser RB: Mutation scanning-based analysis of Theileria orientalis populations in cattle following an outbreak. Electrophoresis 2012, 33:2036-2040.

16. Eamens GJ, Bailey G, Jenkins C, Gonsalves JR: Significance of Theileria orienatalis types in individual affected beef herds in New South Wales based on clinical, smear and PCR findings. Vet Parasitol 2013, 196:96-105.

17. Perera PK, Gasser RB, Anderson GA, Jeffers M, Bell CM, Jabbar A: Epidemioloical survey following oriental theileriosis outbreaks in Victoria, Australia, on selcted cattle farms. Vet Parasitol 2013, 197:509-521. 
18. Auldist MJ, Pyman MFS, Grainger C, Macmillan KL: Comparative reproductive performance and early lactation productivity of Jersey $\times$ Holstein cows in predominantly Holstein herds in a pasture-based dairying system. J Dairy Sci 2007, 90:4856-4862.

19. Thrusfield M: Surveys. In Veterinany Epidemiology. 3rd edition. Ames, lowa: Blackwell Science Ltd; 2005:228-246.

20. Gasser RB, Hu M, Chilton NB, Campbell BE, Jex AJ, Otranto D, Cafarchia C, Beveridge I, Zhu X: Single-strand conformation polymorphism (SSCP) for the analysis of genetic variation. Nat Protoc 2006, 1:3121-3128.

21. Werle E, Schneider C, Renner M, Volker M, Fiehn W: Convenient single-step, one tube purification of PCR products for direct sequencing. Nucleic Acids Res 1994, 22:4354-4355.

22. Larkin MA, Blackshields G, Brown NP, Chenna R, McGettigan PA, McWilliam H, Valentin F, Wallace IM, Wilm A, Lopez R, Thompson JD, Gibson TJ, Higgins DG: Clustal W and Clustal X version 2.0. Bioinformatics 2007, 23:2947-2948.

23. Morton J: Determinants of reproductive performance of dairy cows in commercial herds in Australia. PhD thesis. The University of Melbourne, Faculty of Veterinary Science; 2004.

24. Latif AA, Rowlands GJ, Punyua DK, Hassan SM, Capstick PB: An epidemiological study of tick-borne diseases and their effects on productivity of zebu cattle under traditional management on Rusinga Island, western Kenya. Prev Vet Med 1995, 22:169-181.

25. Muraguri GR, Mbogo SK, McHardy N, Kariuki DP: Cost analysis of immunisation against East Coast fever on smallholder dairy farms in Kenya. Prev Vet Med 1998, 34:307-316.

26. Homewood K, Trench P, Randall S, Lynen G, Bishop B: Livestock health and socio-economic impacts of a veterinary intervention in Maasailand: Infection-and-treatement vaccine against East Coast fever. Agricult Sys 2006, 89:248-271.

27. Kivaria FM: Estimated direct economic costs associated with tick-borne diseases on cattle in Tanzania. Trop Anim Health Prod 2006, 38:291-299.

28. Kivaria FM, Ruheta MR, Mkonyi PA, Malamsha PC: Epidemiological aspects and economic impact of bovine theileriosis (East Coast fever) and its control: A preliminary assessment with special refernce to Kibaha district, Tanzania. Vet J 2007, 173:384-390.

29. Inci A, Ica A, Yildirim A, Vatansever Z, Cakmak A, Albasan H, Cam Y, Atasever A, Sariozkan S, Duzlu O: Economical impact of tropical theileriosis in the Cappadocia region of Turkey. Parasitol Res 2007, 101:S171-S174.

30. Brown CGD: Dynamics and impact of tick-borne diseases of cattle. Trop Anim Health Prod 1997, 29:S1-S3.

31. Sackett D, Holmes P: Assessing the economic cost of endemic disease on the profitability of Australian beef cattle and sheep producers: North Sydney, NSW: Meat and Livestock Australia Ltd.; 2006.

32. Kubota S, Sugimoto C, Onuma M: Population dynamics of Theileria sergenti in persistently infected cattle and vector ticks analysed by a polymerase chain reaction. Parasitology 1996, 112:437-442.

33. Shimizu S, Yoshiura N, Mizomoto T, Kondou Y: Theileria sergenti infection in dairy cattle. J Vet Med Sci 1992, 54:375-377.

doi:10.1186/1756-3305-7-73

Cite this article as: Perera et al.: Oriental theileriosis in dairy cows causes a significant milk production loss. Parasites \& Vectors 2014 7:73.

\section{Submit your next manuscript to BioMed Central and take full advantage of:}

- Convenient online submission

- Thorough peer review

- No space constraints or color figure charges

- Immediate publication on acceptance

- Inclusion in PubMed, CAS, Scopus and Google Scholar

- Research which is freely available for redistribution

Submit your manuscript at www.biomedcentral.com/submit
Ciomed Central 